\title{
TOGETHER OR SEPARATE? \\ CONTRIBUTIONS FROM NEUROEDUCATION TO THE DEBATE ON SEX SEGREGATION IN SCHOOLS
}

\author{
SONIA REVERTER \\ Universitat Jaume I
}

\begin{abstract}
This article analyses the debate on the desirability of separating children by sex in schools. The study reviews the neuroscientific arguments that can inform decisions on this issue. The author starts from the understanding that the education debate should centre its decision not on neuroscientific findings, which are still inconclusive, but on a proposal that evaluates the aim of education. As a new field of study, neuroeducation has the opportunity to draw into the dialogue all the disciplines participating to that end.
\end{abstract}

KEY WORDS: Neuroeducation; Single Sex Education; Co-Education; Sex Difference.

\section{¿Juntos o separados? Contribución desde la neuroeducación al debate sobre la segregación sexual en la escuela}

RESUMEN: en el presente artículo se analizará el debate sobre la conveniencia de separar por sexos a niños y niñas en las aulas. Se partirá de una revisión de los argumentos neurocientíficos que puedan aconsejar una decisión al respecto. Para ello se entenderá que el debate educativo ha de centrar su decisión, no en los hallazgos neurocientíficos, los cuáles hasta el momento no son concluyentes, sino en una apuesta que evalúe el mismo objetivo de la educación. La Neuroeducación, como nuevo campo de estudio, tiene la oportunidad de poner en diálogo todas las disciplinas convenidas a tal fin. PALABRAS CLAVE: Neuroeducación; educación segregada por sexos; coeducación; diferencia sexual.

\section{INTRODUCTION}

The long-running debate on the desirability of separating the sexes in classrooms and schools has repeatedly surfaced on the education agenda ever since co-education became the norm in western democracies ${ }^{1}$. In recent decades, several contextual elements have fuelled interest in the return to single sex education:

1. A wave of conservatism encouraged by the spread of neoliberal governments advocating a return to patriarchal traditions, and ultimately promoting an apolitical view of inequalities among people ${ }^{2}$. This, in

* This research is part of the Project AICO 2020/327, financed by Generalitat Valenciana.

1 See Datnow, A., HubBard, L., "What is the place for single sex schooling in public education?» in: Teachers College Record, 2008, October 13. Also, Younger, M.R. \& WARRINGTON, M., "Would Harry and Hermione have done better in single-sex classes?» in: American Educational Research Journal, 43 (2006), pp. 579-620.

2 See Beck, U. \& Beck-Gernsheim, E., Individualization: Institutionalized Individualism and its social and political consequences (Sage, London, 2002). 
the specific area of gender equality, translates into an individualist and psychologised interpretation of strategies to «be assertive» in gaining equality $^{3}$. This view purports that the empowerment needed to claim the same opportunities is not a social and political struggle, but rather a question of willpower and individual merit ${ }^{4}$.

2. A neoliberal interest in regarding education first and foremost as training in practical skills and knowledge that allow the market to develop and perform effectively ${ }^{5}$. In some way, this appears to compel inquiry into whether there are learning differences between the sexes that might be taken into account and explored for the efficiency of these market purposes.

3. A profusion of scientific studies that reach two different conclusions on co-education: persistent low performance outcomes among boys, and the recurrent pattern of girls choosing not to take science, technology, engineering and mathematics (STEM) subjects ${ }^{6}$. This is generally interpreted as evidence to support the orientation of boys and girls towards differentiated learning models based on the idea that some areas of competence are determined by biological questions associated with sex differences ${ }^{7}$. This sex differentiation is therefore understood to advocate different educational guidelines for groups segregated by sex.

4. The rising number of neuroscientific studies and their incorporation into the education debate as the key to understanding how the brain functions in the learning process. In this vein, although there are no conclusive

3 See Adamson, M., "Postfeminism, Neoliberalism and A "Successfully" Balanced Femininity in Celebrity CEO Autobiographies» in: Gender, Work and Organization 24/3 (2017), pp. 314-27.

4 See Fraser, N., Fortunes of Feminism. From state-managed capitalism to neoliberal crisis (Verso, London, 2013). Also, Brown, W., Undoing the Demos: Neoliberalism's Stealth Revolution (MIT Press, Zone Books, Cambridge, MA, 2017).

5 See Aronowitz, S. \& Giroux, H. A., Education Under Siege: The Conservative, Liberal and Radical Debate Over Schooling (Routledge \& Kegan Paul, London, 1987). Also, Lipman, P., The New Political Economy of Urban Education: Neoliberalism, Race, and the Right to the City (Routledge, Taylor \& Francis, London, 2011).

6 See Sмyтн, E., «Single-sex Education: What Does Research Tell Us» in: Revue française de pédagogie 171 (2010), 47-58. Also, UNGEI (United Nations Girl Education Initiative), Why are Boys Under-performing in Education? https://www.unicef.org/.../report_why_are_boys_ underperformin... (2012). Also, OECD, Education at a Glance 2015: OECD Indicators, OECD Publishing. http://dx.doi.org/10.1787/eag-2015-en (2015). Also, OECD, Education at a Glance 2017: OECD Indicators, OECD Publishing, Paris. http://dx.doi.org/10.1787/eag-2017-en (2017). Also, Hillman, N. \& Robinson, N., Boys to Men: The underachievement of young men in higher education-and how to start tackling it (Oxford, Higher Education Policy Institute, «HEPI Report 84», 2016). Stoet, G. \& Geary, D. C., «The Gender-Equality Paradox in Science, Technology, Engineering, and Mathematics Education», in: Psychological Science (2018), pp. 1-13.

7 GhazVinia, S. D. \& Khajehroura, M., "Gender differences in factors affecting academic performance of high school students», in: Procedia Social and Behavioral Sciences, 15 (2011), pp. 1040-1045. 
studies as yet, there is a clear tendency in scientific journals, as criticised by some members of the scientific community ${ }^{8}$, to mainly publish reports on sex differences, not similarities, in brains. This leads to the patently acritical and uncorroborated assumption that sex differences in brains are decisive in cognition processes ${ }^{9}$.

Taken together, these four points seem to clearly suggest that education must take sex difference into account. However, this assertion is riddled with questions that require further clarification: What does 'taking sexual difference into account' mean? Does it inevitably mean girls and boys should be separated at school? What do the neuroscientific arguments add to the debate on the main purposes of education?

To clarify these questions, we propose a reflection centred on the following three points:

1. What is neuroeducation?

2. What is the current state of the question of sex difference in cognition?

3. What is the purpose of education?

\section{What IS NEUROEDUCATION?}

Our attempt to understand the new field of study known as «neuroeducation» ${ }^{10}$ starts from the notion that the debate in education on sex difference must take into account the differences that biology uncovers and demonstrates, but also that the educational institution's role in producing/reproducing social and cultural gender differences (and their possible transformation into inequalities) must be monitored. In this sense, «neuroeducation» offers a field for fertile dialogue between disciplines associated with brain research and those concerned with education and pedagogy. As many authors have repeatedly stated, this relationship must be genuinely dialogue based, and an important question, although beyond the scope and aims of this paper, will be to ascertain how we understand this meeting point between educational and neuroscientific disciplines. In other words: What is the orientation of the relationship between

8 REVERTER-BAÑón, S., «El Neurofeminismo frente a la investigación sobre la diferencia sexual», in: Daimon. Revista Internacional de Filosofía, 6 (2017), pp. 95-110.

9 VIDAL, C., «The Sexed Brain: Between Science and Ideology», in: Neuroethics, 5/3 (2011), pp. 295-303.

${ }_{10}$ In The Educated Brain. Studies in Neuroeducation (Cambridge University Press, Cambridge, 2008), the editors Battro, A.; Fisher, K. \& Lena. P. J. refer to two different lines in attempts to align «mind, brain and education». One is neuroeducation itself, the main endeavour of which is to create a transdisciplinary connection; the other is «educational neuroscience», which focuses on the way neuroscience might improve education. We do not go into this distinction in the present paper, but rather propose the term «neuroeducation» as a new field of enquiry into mind, brain and education that must necessarily be transdisciplinary. 
these two fields of knowledge? Who is leading the way? Is it a symmetrical direction? Is there a two-way, mutual influence? In 2004, the philosopher and neuroscientist Georg Northoff ${ }^{11}$ concluded that the relationship between philosophical theories and scientific hypotheses is transdisciplinary, in that it implies something more than the mere synthesis and combination of certain hypotheses with others, which would be considered interdisciplinary. The new field of neuroeducation must clarify this transdisciplinary dialogue ${ }^{12}$.

Although the term is as new, broad and vague as any of the other "neuro» labels ${ }^{13}$, it can be defined within this transdisciplinary conception we identify as a meeting point for views on the mind, brain and education, where dialogue between theories and methodologies is proposed ${ }^{14}$. The main purpose of this encounter is to explore the scientific and pedagogic bases of learning and education ${ }^{15}$ in order to arrive at a point where we can use knowledge from all the participating disciplines. It is important to note that our aim in defending dialogue among disciplines is to avoid the generally accepted route that considers neuroeducation should transfer neuroscientific evidence to the sphere of education in order to improve students' learning at school ${ }^{16}$. In other words, we do not understand neuroeducation as a discipline that is anticipating proven neuroscientific revelations that will simply be subsumed

11 See Northoff, G., «What Is Neurophilosophy? A Methodological Account», in: Journal for General Philosophy of Science, 35 (2004), pp. 91-127.

12 For a fascinating history of the attempts to build bridges between brain research and educational enquiry, we refer readers to Theodoridou, Z. \& Triarhou, L. In their article "Fin-de-Siecle Advances in Neuroeducation: Henry Herbert Donaldson and Reuben Post Halleck» (Mind, Brain and Education, 3/2 (2009), 119-129), the authors analyse two earlier explorations of neuroeducation; first that of neurologist Herbert Donaldson (1857-1938) in his book The Growth of the Brain: A Study of the Nervous System in Relation to Education (1895); and second, the work of educator Reuben Post Halleck (1859-1936), as reflected in his book The Education of the Central Nervous System: A Study of Foundations, Especially of Sensory and Motor Training (1896). In their respective publications at the end of the 19th century, these authors make a significant contribution to current debate on the (inter- and trans-) relationship between the neurosciences and education. The central issues on which current debate on gender, neuroplasticity, nature and nurture hinges are to be found in their work.

13 For a concise history of the neologism «neuro», see the chapter by VIDAL, F., "Historical Considerations on Brain and Self», in Battro, A. M., Fischer, K. W. \& LÉna, P. J. (eds.), The Educated Brain (Cambridge University Press, Cambridge, 2008), 20-42. Also, the book by VidAL, F. \& ORTEGA, F., Being Brains. Making the Cerebral Subject (Fordham University Press, New York, 2017).

14 Ansari, D., de Smedt, B. \& Grabner, R. H., «Neuroeducation - A Critical Overview of An Emerging Field» in: Neuroethics, 5/2 (2012), pp. 105-117.

15 Nouri, A. \& Mehrmohammadi, M., «Defining the Boundaries for Neuroeducation as a Field of Study» in: Educational Research Journal, 27/1-2 (2012), pp. 1-25.

16 Crifaci, G., Città, G., Raso, R., Gentile, M. \& Allegra, M., «Neuroeducation in the light of Embodied Cognition: an innovative perspective», in: Recent Advances in Educational Technologies, 21-24 (2015), 21-24. Available: http://www.inase.org/library/2015/zakynthos/ bypaper/EDU/EDU-03.pdf 
into the explanation of how the learning process occurs. This implies not a dialogic vision, as we defend here, but a relationship in which education is subordinated to neuroscientific advances, which is the view normally held even when it is labelled «interdisciplinary» (as Patricia M. Greenfield points out in her review of understanding on the relationships between culture and biology $)^{17}$. This asymmetrical relationship is precisely that assumed in the conception of neurophilosophy originally expressed by Patricia Churchland ${ }^{18}$, and that we challenge here. In response to this, we refer to neuroeducation as the set of disciplines integrated in a dialogue-based mind-brain-education research programme, or to borrow John Bruer's ${ }^{19}$ metaphor, that builds bridges and does not pursue fundamentals. The preface to one of the most recent studies that reviews this relationship in depth, Philosophical Reflections on Neuroscience and Education, cautions as follows:

The education-neuroscience experiment is one massive error! That is the overriding sentiment of what you are about to read. I make no apologies for this bleak and overtly negative outlook. Indeed, there is little positive to say about the neuroscience venture into educational discourse at all; except maybe to show us how collaborative research ought not to be conducted ${ }^{20}$.

As part of our conclusion on this conceptual debate we share the notion that neuroeducation must ask ethical questions before attempting to «translate» scientific findings into educational instructions ${ }^{21}$. This leads us, as we will see in the final part of this article, to the debate on what we understand the school must do to educate our children; and this cannot be dictated by the neurosciences.

Against this background, we now turn to the purpose of this article, which is to try and briefly clarify the state of the question of purported sex differences in the brain as an introduction to the debate on single sex or co-education in the school.

Of the four contextual elements noted above to explain the growing political and social interest in the subject of single sex schooling, it is the fourth point, the neuroscientific argument, that may hold the greatest

17 See Greenfield, P. M., «The mutual definition of culture and biology in development», in Keller, H., Poortinga, Y. H. \& Schölmerich, A. (eds.), Between Culture and Biology. Perspectives on Ontogenetic Development (Cambridge University Press, Cambridge, 2002), pp. 57-76.

18 Churchland, P., Neurophilosophy: toward a unified science of the mind-brain (MIT Press, Boston, 1986)

19 See Bruer, J. T., «Education and the Brain: A Bridge Too Far», in: Educational Researcher, 26/8 (1997), 1-13. And by the same author, «Building bridges in neuroeducation», in Battro, A. M. et al. (eds.) The Educated Brain (Cambridge University Press, Cambridge, 2008), pp. 43-58.

20 In Kitchen, W. H., Philosophical Reflections on Neuroscience and Education (Bloombsbury, London, 2017), p. xi.

21 Hardiman, M., Rinne, L., Gregory, E., et al., "Neuroethics, Neuroeducation, and Classroom Teaching: Where the Brain Sciences Meet Pedagogy», in: Neuroethics, 5/2 (2012), pp. 135-143. 
sway in favour of either co-education or segregation; and for this reason, it has tended to lie at the heart of debate in the last decade. This is not only because of the "scientific authority» of its argumentations, but also because of the growing interest in the brain during these years. All of this situates neuroscientific discourse as a kind of revelation of the truth about what we are $^{22}$, although it is often riddled with prejudices and neuromyths ${ }^{23}$. As Schafer recently claimed, "the physical world has become the paradigm of intelligibility - and locating some phenomenon in that world has become the preferred method for rendering that phenomenon philosophically intelligible or legitimate ${ }^{24}$. Our question is whether the neurosciences, whose discourse accrues legitimacy from the physical evidence on the world they discover, are in a position to decide whether our children should be co-educated or taught in single sex classrooms. But before we address this issue at the end of the article, we explore another question that provides the foundations on which to base our decision: have the neurosciences uncovered physical evidence of sex differences in cognition?

\section{WHAT IS THE STATE OF THE QUESTION ON SEX DIFFERENCE IN COGNITION?}

Understanding sex difference takes us to a historical trajectory which shows that the very concept of «sex difference», far from being clear and concise, is plagued with historical and contextual nuances ${ }^{25}$. Although we cannot explore this history here, it is interesting to note what Laqueur ${ }^{26}$ has to say on the matter: for example, he states that sex difference in a period up to the eighteenth century was understood as continuous, and after a certain point it began to be regarded as discrete. The biological disciplines, as Russet ${ }^{27}$ describes in her classic study, attempted throughout the twentieth century to find elements in the brain that would explain sex differences, which were apparently beyond question. The historical narrative shows the variability in determining the

22 See Vidal, F. \& Ortega, F., Being Brains. Making the Cerebral Subject (Fordham University Press, New York, 2017).

23 See for example, Howard-Jones, P. A., "Neuroscience and education: myths and messages», in: Nature Reviews Neuroscience, 15/12 (2014), 817-824. Also, ReVERTER-BAÑón, S. \& Medina-Vicent, M., "La diferencia sexual en las neurociencias y en la neuroeducación», in: Crítica. Revista Hispanoamericana de Filosofía, 50/150 (2018), 3-26. And, Reverter, S., «El diálogo en las ciencias cognitivas frente a la controversia de la coeducación», in: Sophia, colección de Filosofía de la Educación, 30 (2021), pp. 71-93.

${ }_{24}$ In Schafer, K., "Hard Problems between Minds and Bodies», Philosophy and Phenomenological Research, 96/1 (2018), pp. 224-232.

25 REVERTER-BAÑón, S., «El Neurofeminismo frente a la investigación sobre la diferencia sexual», in: Daimon. Revista Internacional de Filosofía, 6 (2017), pp. 95-110.

26 In Laqueur, T., Making Sex: Body and Gender From the Greeks to Freud (Harvard University Press, Cambridge MA, 1990).

27 In Russett, C.E., Sexual Science: The Victorian Construction of Womanhood (Harvard University Press, Cambridge MA, 1989). 
frame of what we understand by sex difference. Today, this narrative is mainly linked to scientific enquiry; and what is its ruling?

We look at two recent examples of acclaimed scholars in this subject.

The neuropharmacologist Margaret McCarthy, renowned for her work on sex/gender differences in mental and neurological disturbances, claims the conversation on sex differences in the brain is not yet over, since no conclusive arguments have been reached. To date, her most forceful message is: «[...] the unavoidable conclusion that there cannot be uniform masculinization or feminization of the entire brain ${ }^{28}$.

For her part, and in the same line, in her recent studies the behavioural neuroscientist Daphna Joel finds that the structural differences between male and female brains are too scarce and lacking in significance to continue justifying the existence of sex differences between them; rather, she argues that the brain lies on a femaleness-maleness continuum. The maleness end of the continuum contains elements more typical of male subjects, and the femaleness end, those more typical of female subjects, the aim being to find out where each individual brain, examined region by region, falls on this continuum. Hence, Joel and colleagues conclude: "Our results demonstrate that regardless of the cause of observed sex/gender differences in brain and behavior (nature or nurture), human brains cannot be categorized into two distinct classes: male brain/female brain ${ }^{29}$. They argue that the brain is a mosaic, and that very few brains - between $0 \%$ and $8 \%$ according to their studies - contain all the female or all the male elements.

That sex differences in the brain are unsubstantiated was affirmed by psychologist Janet Hyde, who in «The Gender Similarities Hypothesis» ${ }^{30}$, a widely cited seminal paper in sex difference research, concludes from a metaanalysis $^{31}$ that most studies do not confirm this purported difference in the brain.

28 In Joel, D. \& Mccarthy, M., «Incorporating Sex as a Biological Variable in Neuropsychiatric Research: Where Are We Now and Where Should We Be?», in: Neuropsychopharmacology, 42 (2017), pp. 379-385.

29 Joel. D. et al., «Sex beyond the genitalia: The human brain mosaic», in: Proceedings of the National Academy of Sciences (PNAS), 112/50 (2015), pp. 15468-15473.

30 Hyde, J. S., "The Gender Similarities Hypothesis», in: American Psychologist, 60/6 (2005), pp. 581-592.

31 The meta-analysis analysed 46 studies on the psychological differences in gender available at that time. The 46 studies found 124 effect sizes for gender differences. Surprisingly, $30 \%$ of the effect sizes were between 0 and 0.10 , and a further $48 \%$ were in the range of a small difference of between 0.11 and 0.35 . In other words, $78 \%$ of the gender differences were small or very close to 0 . These results led Hyde to propose the gender similarities hypothesis, as opposed to the usual differences model. In 2015 another study tested the gender similarities hypothesis, reaching a very similar conclusion: $39 \%$ were close to zero and $46 \%$ were very small. See reflection on this in Zelle, K. Z. \& Teeter, S. R., «Evaluating gender similarities and differences using metasynthesis», in: Am Psychol, 70 (2015), pp. 10-20. 
As neurologist Lise Eliot ${ }^{32}$ states, it therefore appears to be an unproven hypothesis. Notwithstanding, however unproven or inconclusive it may be, this hypothesis seems to have taken hold in the public imagination, influencing our beliefs about children's educational needs.

A further important point is to understand how, if there are sex differences in the brain, they influence the mind and behaviour. It is here that the naturenurture debate reappears, and where the thesis of brain plasticity and epigenesis become crucial.

Clearly, if we start from the conviction - scientifically demonstrated or notthat there is a sex difference which has a significant influence on learning, and therefore on education, we must understand what it is. In other words, what «sex difference» is exactly, and where it is found.

One of the classic arguments in neuroscientific research into sex differences in the brain concerns the difference in terms of the connection between brain hemispheres. In 2014, the expert in biomedical image analysis Madhura Ingalhalikar ${ }^{33}$ and her colleagues concluded that "female brains» (the brains of people identified as female) have a greater connection between hemispheres, whereas those of people identified as male presented greater connectivity within each hemisphere. The study used a variation of magnetic resonance technology - diffusion tensor imaging - that generates a map of water diffusion in different parts of the brain in a study of 949 young people aged between 8 and 22, 428 male and 521 female. According to the authors of this widely cited and discussed study, their results suggest that male brains are structured to facilitate the connection between perception and action, whereas female brains are designed to facilitate communication between analytical and intuitive processes. It is significant that Ingalhalikar and her colleagues use the expression "are designed» (as Ayala, Belli and Broncano note ${ }^{34}$ ) to refer to the brain's structure, when the same study states that the differences appear in adolescence (between 13 and 17) and young adulthood (between 17 and 22). What occurs in the previous years? Might the differences they observed be the result of a sex-differentiated education? Although the most common interpretation of this study is that men and women are different by nature, and this is the version transmitted to the mass media, the study itself does not provide any evidence to this effect: this «design» differentiated by sex may be the design that our sexist education and culture impose from birth; a cultural context that precisely, and because of the difference in gender socialisation, motivates boys to be competitive and develop motor skills and girls to cooperate and help the most vulnerable.

32 See Eliot, L., «The Trouble with sex differences», in: Neuron, 72/6 (2011), 895-898. And by the same author, «Single-Sex Education and the Brain», in: Sex Roles, 69/7-8 (2013), pp. 363-381.

33 Ingalhalikar, M., Smith, A., Parker, D. et al., "Sex differences in the structural connectome of the human brain», in: PNAS, 111/2 (2014), pp. 823-828.

34 In Ayala, S., Belli, S. \& Broncano, F., «Diferencias, discriminación, cerebro y sexo: controversias científicas de lo social y lo biológico», in: Encrucijadas, 8 (2014), pp. 3-9. 
A recent investigation analysing studies such as Ingalhalikar's, among others, concludes that underlying neuroimaging research:

[...] we did not find empirical support for the hypothesis that sex differences in the global structural connectome organization underlie enhanced spatial ability in men and verbal ability in women. Thus, the reported results highlight the crucial relevance of testing the functional role, at the individual level, of sex-dependent differences in brain features for avoiding arguable interpretations ${ }^{35}$.

Methodological biases such as those identified in studies like Ingalhalikar's tend to establish unjustified correlations between observable differences in the brain and social differences. This transfer from the brain to human behaviour is one of the stages considered to contaminate the scientific process ${ }^{36}$. It is clearly possible to speak of unscientific or pseudo-scientific conclusions, and certainly of science fed and distorted by a sexist culture ${ }^{37}$.

The psychologist Diane F. Halpern ${ }^{38}$, recognised for her work on sex differences in cognition, proposes a biopsychosocial model as a better way of understanding human cognition and its variability. The dichotomous frame that evaluates sex differences in terms of nature-nurture is very simple and inadequate, since to her mind, it hinders comprehension of human complexity. Miller and Halpern's ${ }^{39}$ review of changes in relation to sex differences in cognition suggests that the changes in recent decades in the results measuring mathematics skills (with an obvious decline in the differences between boys' and girls' results in recent decades, and negligible differences today) suggest that cultural factors, such as gender equality, can reverse sex differences (whether or not they are found in the brain) $)^{40}$.

35 Martínez, K., Janssena, J., Pineda-Pardof, J. A. et al., "Individual differences in the dominance of interhemispheric connections predict cognitive ability beyond sex and brain size», in: NeuroImage, 155 (2017), pp. 234-244,.

36 See VIDal, C., "The Sexed Brain: Between Science and Ideology», in: Neuroethics, 5/3 (2011), 295-303. Also, Fausto-Sterling, A., Sexing the Body. Gender Politics and the Construction of Sexuality (Basic Books, New York, 2000). And Fausto-Sterling, A., "How else can we study sex differences in early infancy?», in: Developmental Psychobiology, 58/1 (2015), pp. 5-16.

37 See Fine, C., Delusions of Gender: How Our Minds, Society and Neurosexism Create Difference, (Icon Books, London, 2010).

38 Halpern, D. F., Sex Differences in Cognitive Abilities (Psychology Press, Taylor \& Francis, New York and Hove 2012. First edition, 1986).

39 Miller. D. I. \& Halpern, D. F., «The new science of cognitive sex Differences», in: Trends in Cognitive Sciences, 18/1 (2014), pp. 37-45.

40 The concept of epigenesis, linked to cerebral plasticity, is particularly relevant to this line of thought. Neuroscience speaks of the malleability of the brain throughout life and the constant dynamic interaction with the environment; however, according to Rogers (2010: S8): "Despite this evidence of interactive processes, some scientists continue to hold great hope of finding sex differences in the expression of genes in the human fetus». In RogERS, L., "Sexing the Brain: The Science and Pseudoscience of Sex Differences», in: Kaohsiung Journal of Med Sci, 26/6 (2010), S4-S9. 
In a cultural landscape rife with sexual stereotypes, what is known as the «stereotype threat» ${ }^{41}$ is a frequent phenomenon that alludes to the risk of conforming to a negative stereotype of the social group to which an individual belongs. These theses elaborate on the importance of proposing interdisciplinary theories and methods that integrate understanding of the brain, cognition and culture. Not only would it be desirable to have a more fertile interdisciplinary relationship between brain sciences and cultural sciences, as we argue here, but also a new non-dichotomous frame to explain the relationship between nature and nurture. Whatever the case, as FaustoSterling ${ }^{42}$, an authority in the debate on sex differences in the brain, has repeatedly stated: «we insist that to study difference we must begin before it exists and observe its emergence».

\section{What IS THE PURPOSE OF EDUCATION?}

Sex difference in cognition is, in some way, interpreted as obliging education to be organised according to these cognitive differences, which leads on to arguments advocating the desirability of separating boys and girls. However, as we have seen, this cognitive sex difference is by no means clear, nor can we be certain whether it leads to differences in learning models ${ }^{43}$, or whether separation by brain groups results in a greater willingness to learn. What is clear is that any response to these questions requires a well-defined vision of the purpose we propose for education.

There is currently a great deal of discussion about what the primary purpose of education is, which to some degree is revolutionising the debate about school, immersed for decades in deliberations over whether it should prepare efficient workers or free citizens. Interest in education as a vehicle that may be harnessed for the benefit of industry and the economy has a long history that can be traced back to Adam Smith's theories of modern economy. In the 1950s, aligned with the concept of human capital, the notion of the worker as a decisive factor for business production and economic growth began to emerge. The

${ }^{41}$ The concept of «stereotype-threat» is defined in relation to a situation in which a person feels or is at risk of adapting to the stereotypes about a social group. It is understood to be a factor that potentially contributes to the long-standing racial and gender disparities in academic performance. The concept is attributed to Steele, C. M. \& Aronson, J., «Stereotype threat and the intellectual test performance of African Americans», in: Journal of Personality and Social Psychology, 69/5 (1995), pp. 797-811.

42 In Fausto-Sterling, A., Garcia Coll, C. \& Lamarre, M., «Sexing the baby: Part 1-What do we really know about sex differentiation in the first three years of life?», in: Social Science \& Medicine, 74 (2012), pp. 1684-1692.

43 See Eliot, L., "The Trouble with sex differences», in: Neuron (2011) 72(6), 895-898. And by the same author, «Single-Sex Education and the Brain», in: Sex Roles, 69/7-8 (2013), pp. 363-381. 
work of Gary Becker ${ }^{44}$ and Theodore Schultz ${ }^{45}$ in the sixties helped to establish the idea of investment in education as fundamental to countries' growth and development. Later studies, such as those of Thurow ${ }^{46}$ and Mincer ${ }^{47}$, among others, also emphasised the importance of education to enhance workers' wellbeing and quality of life. By the end of the 1970s, as Ball ${ }^{48}$ notes, education had been firmly established on the main government policy agenda, with economic interests prioritised and workers' personal well-being left in the shadows. One of the most notable turning points in global educational reforms and changes is government intervention in schooling beyond the state's duties to defend what is public. The control of schools by government administrators has been rolled out as the appropriate way to plan and develop education.

This change has led to what the internationally renowned educator and scholar Pasi Sahlberg ${ }^{49}$ has termed the "global education reform movement», or GERM. This author locates the symptoms of this global reform in three visible elements: the standardisation of curricula to compete - between schools, between teachers and between students; establishment of school choice for parents, since the school is a marketplace that must provide a wide offer from which consumers can choose the product; and finally, accountability, which is rendered as a statistical idea of accountability through the continual evaluation and measuring of processes and results. As Sahlberg warns, all of these developments distance teaching from the art of pedagogy, moving it towards mechanical, automated and bureaucratised instruction (and management).

From this description, we understand that segregated education aligns closely with each one of these three global trends in education. Hence, a segregated school can standardise curricula more easily because it is based on the homogenisation of groups. At the same time, it increases the variety of education on offer, which is attractive for a market based on giving parents a wide range of choices and dressing up the right to choose as the pinnacle of freedom in performing their parental roles. And finally, it allows processes and performance to be measured and evaluated homogenously, without the need to consider gender variables; in other words, without taking into

44 Becker, G. S., Human Capital (Columbia University Press for the National Bureau of Economic Research, New York, 1964, 1st ed.).

45 Schultz, T. W., "Capital formation by education», in: The journal of political economy, 68/6 (1960), pp. 571-583.

46 Thurow, L. C., «Education and Economic Equality», in: The Public Interest, 28 (1972), pp. 66-81.

47 Mincer, J., Schooling, Experience, and Earnings, (National Bureau of Economic Research. New York, Columbia University Press, 1974).

48 Ball, S. J., The Education Debate (Bristol, Policy Press, 2017, third edition).

49 SAHLberg, P., Finnish Lessons: What Can the World Learn from Educational Change in Finland? (Teachers College Press, New York, 2011). And Sahlberg, P., HasaK, J. \& Rodriguez, V., Hard Questions on Global Educational Change Policies, Practices, and the Future of Education (Teachers College Press, New York, 2017). 
account the socio-cultural construction of what is female and male. This line of argument offers an explanation for the growing interest in single sex education within part of the scientific and educational community. And this aligns with the first two contextual elements in the education debate: a wave of conservativism that advocates separation of gender roles, and a neoliberal interest in efficient learning to develop the professions the market demands, pushing into the background what, we argue here, should be the principal purpose of education: the formation of values for a fairer, more egalitarian and human world.

\section{Conclusions}

Apart from these tendencies, which may be regarded as «ideological», the arguments in favour or against single sex and co-education must be firmly set out. The literature reviewing data on education provides no conclusive advantages for either single sex or co-education ${ }^{50}$. The international association Gender and Education (GEA), created in 2002 with the aim of eradicating sexism and gender inequality in education, clearly states: «[...] we lack consistent, robust evidence about the advantages of one school type over the other $»^{51}$.

The conclusions that do seem to be unequivocal are, however, the importance of a well-designed curriculum to improve cognitive skills and educational performance in both sexes. This points to the relevance of cerebral plasticity in understanding and planning social changes from within education ${ }^{52}$. In this line, removing gender inequalities and the "stereotype threat» could improve academic performance for men and women, girls and boys ${ }^{53}$. Epigenetic studies show promise in extending knowledge on how genetic modifications

50 See Mael, F., Alonso, A., Gibson, D., Rogers, K. \& Smith, M., Single-sex Versus Coeducational Schooling: A Systematic Review (US Department of Education, Washington DC, 2005). Also, Pahlke, E., Hyde, J. S. \& Allison, C. M., «The Effects of Single-Sex Compared with Coeducational Schooling on Students' Performance and Attitudes: A Meta-Analysis», in: Psychological Bulletin American Psychological Association, 140/4 (2014), 1042-1072. And, HalPern, D. F., Sex Differences in Cognitive Abilities (Psychology Press, Taylor \& Francis, New York and Hove, 2012. First edition, 1986).

51 See in GEA-Gender and Education (2013) http://www.genderandeducation.com/ resources-2/pedagogies/singlesex-coeducation/

52 MAY, A., «Experience-dependent structural plasticity in the adult human brain», in: Trends in Cognitive Sciences, 15 (2011), pp. 475-482.

53 See Mryake, A. et al., "Reducing the gender achievement gap in college science: a classroom study of values affirmation», in: Science, 330 (2010), 1234-1237. Also, HARTLEY, B. L. \& Sutton, R. M., "A stereotype threat account of boys' academic underachievement», in: Child Dev, 84 (2013) 1716-1733. And, Weber, D., SkirbekK, V., Freund, I. \& Herlitz, A., «The changing face of cognitive gender differences in Europe», in: PNAS, 111/32 (2014), pp. 11673-11678. 
can originate, according to McCarthy et al. ${ }^{54}$, as a result of causes such as «life experiences, hormonal exposure, trauma and injury, learning and memory». This growing line of research will open up new horizons in the debate on sex differences in the brain ${ }^{55}$, which to date, far from proving the desirability of single sex education, suggests that educational policies based on promoting equality and removing stereotypes play a major role in and have an impact on improving educational performance for girls and boys. As long as the neurosciences are unable to provide conclusive experimental results in favour of either single sex or co-education, we argue that the education debate must advance proposals and consolidate a framework that promotes the equality necessary for cooperative learning grounded on diversity, because ultimately that is how we live and how educational institutions at the highest level, like the OECD, urge us to understand education ${ }^{56}$.

We conclude by clearly stating the thesis defended in this paper on what the purpose of neuroeducation should be: to construct a transdisciplinary dialogue that places the education debate at its heart. And to do this, although the debate on sex difference remains open and inconclusive, scientific findings should not determine what and how we educate. In our view, even if cognitive sex differences were proven, it would not inevitably imply that children should be segregated by sex in schools and/or classrooms. Sex or any other type of cognitive difference, if it does indeed exist, is not an argument that directly endorses separation by groups in the teaching-learning process. Furthermore, as a large sector of the education community contends, diversity in the classroom is better able to promote learning than homogeneity ${ }^{57}$. In addition, if the differences between individuals are so important in the learning-teaching process, we must also bear in mind the role of the school as an institution that helps to construct/deconstruct children's sex/gender identity, as Askew and Ross highlighted in 1988 in their now classic book Boys Don't Cry: Boys and Sexism in Education ${ }^{58}$.

What we have argued in this paper is that neuroeducation opens up the opportunity for critical dialogue among disciplines. In this dialogue, the neurosciences have yet to provide any conclusions on whether sex-segregated education yields better results; and yet we do have robust conclusions about the importance that starting from gender equality policies has in improving

54 Mccarthy, M.A. et al., "The Epigenetics of Sex Differences in the Brain», in: The Journal of Neuroscience, 29/41 (2009), pp. 12815-12823.

55 Auger, A. P. \& Mccarthy, M. A., «Epigenetic Contribution to Sex Differences in Brain and Behavior», in Pfaff, D. W. \& JoËLs, M. (eds.), Hormones, Brain and Behavior (Elsevier Academic Press, Amsterdam, 2017. Third Edition), pp. 49-62.

56 See Burns, T. \& Köster, F. (eds.) Governing Education in a Complex World, (OECD Publishing, Paris, 2016).

57 See CIN, F. M., Gender Justice, Education and Equality Creating Capabilities for Girls' and Women's Development (Palgrave Macmillan, London, 2017).

58 Askew, S. \& Ross, C., Boys Don't Cry: Boys and Sexism in Education (Open University Press, Milton Keynes, 1988). 
young people's educational performance ${ }^{59}$. And experience has shown that these equality policies are more likely to be implemented in a co-education system $^{60}$.

Universitat Jaume I (Castellón de la Plana)

SONIA REVERTER

Departamento de Filosofía y Sociología

reverter@uji.es

[Artículo aprobado para publicación en febrero de 2021]

59 GuISo et al.'s analysis of PISA reports is particularly relevant on this point and demonstrates that, based on the evidence, we can confirm that «the gender gap in math scores disappears in countries with a more gender-equal culture» (2008: p. 1164). GuIso, L., Monte, F., Sapienza, P. \& Zingales, L., Culture, Gender, and Math, "Science» 320/6 (2008), 1164-1165. See also, Corbett, C. \& Hill, C., Where the Girls Are: The Facts about Gender Equity in Education. Executive Summary (AAUW Educational Foundation, Washington, 2008). And, KLEIN, S. (ed.) Handbook for Achieving Gender Equity Through Education (Routledge. Taylor and Francis Group, New York, 2007). Also, FASSA, F., Rolle, V. \& Storari, C., «Politiques de l'égalité à l'école obligatoire. Des ambivalences qui diluent les rapports sociaux de sexe», in: Swiss Journal of Sociology, 40/2 (2014), 197-213. Also, FAssA, F., Filles et garçons face à la formation. Les défis de l'égalité (Presses polytechniques et universitaires romandes, Lausanne, 2016). And van Hek, M., KraAykamp, G. \& Pelzer, B., «Do schools affect girls' and boys' reading performance differently? A multilevel study on the gendered effects of school resources and school practices», in: School Effectiveness and School Improvement, 29/1 (2017), pp. 1-21.

60 See UNESCO, Education 2030 Framework for Action, Incheon Declaration and Framework for Action for the implementation of Sustainable Development Goal 4 (UNESCO, Paris, 2015). Also, Chaluda, A., Ensure Equitable and Quality Education at All Levels. Report for DELIVER FOR GOOD (http://womendeliver.org, New York, 2017). 